Technological University Dublin

DÜBLIN

ARROW@TU Dublin

2004-01-01

\title{
Ionizing Radiation Induces a Stress Response in Primary Cultures of Rainbow Trout Skin
}

\author{
Fiona Lyng \\ Technological University Dublin, fiona.lyng@tudublin.ie \\ M. Lyons-Alcantara \\ Marine Institute of Ireland \\ P. Owell \\ Technological University Dublin
}

See next page for additional authors

Follow this and additional works at: https://arrow.tudublin.ie/radart

Part of the Radiology Commons

\section{Recommended Citation Radiation Research, Vol.162, 2, pp.226-232. doi:10.1667/RR3216 \\ This Article is brought to you for free and open access by the Radiation and Environmental Science Centre at ARROW@TU Dublin. It has been accepted for inclusion in Articles by an authorized administrator of ARROW@TU Dublin. For more information, please contact arrow.admin@tudublin.ie, aisling.coyne@tudublin.ie, gerard.connolly@tudublin.ie.}

Lyng, F. et al (2004) lonizing radiation induces a stress response in primary cultures of rainbow trout skin.

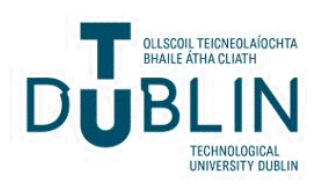




\section{Authors}

Fiona Lyng, M. Lyons-Alcantara, P. Owell, Sharon Ni Shuilleabhain, Colin Seymour, D. Cottell, and Carmel Mothersill

This article is available at ARROW@TU Dublin: https://arrow.tudublin.ie/radart/22 


\title{
Ionizing Radiation Induces a Stress Response in Primary Cultures of Rainbow Trout Skin
}

\author{
F. M. Lyng,,$^{a, 1}$ M. Lyons-Alcantara, ${ }^{b}$ P. Olwell, ${ }^{a}$ S. Ní Shuilleabháin, ${ }^{a}$ C. Seymour, ${ }^{c, 2}$ D. C. Cottell ${ }^{d}$ and C. Mothersill ${ }^{a, 2}$ \\ ${ }^{a}$ Radiation and Environmental Science Centre, Dublin Institute of Technology, Kevin Street, Dublin 8, Ireland; ${ }^{b}$ Marine Institute, Marine Institute, \\ Snugboro Road, Abbotstown, Dublin 15, Ireland; ' St Luke's Hospital, Highfield Road, Rathgar, Dublin 6, Ireland; and ${ }^{d}$ Electron Microscopy \\ Laboratory, University College Dublin, Belfield, Dublin 4, Ireland
}

Lyng, F. M., Lyons-Alcantara, M., Olwell, P., Ní Shuilleabháin, S., Seymour, C., Cottell, D. C. and Mothersill, C. Ionizing Radiation Induces a Stress Response in Primary Cultures of Rainbow Trout Skin. Radiat. Res. 162, 000-000 (2004).

Fish skin is very vulnerable to damage from physical and chemical pollutants because it is in direct contact with the aquatic environment. In this study, the effect of $\gamma$ radiation on primary cultures of rainbow trout skin was investigated. Primary cultures containing two cell types, epidermal cells and goblet mucous cells, were exposed to doses ranging from 0.5-15 Gy ${ }^{60} \mathrm{Co} \gamma$ radiation. Expression of PCNA, c-myc and BCL2 was investigated as well as growth and levels of apoptosis and necrosis. Morphological and functional changes were also studied. The irradiated cultures showed evidence of a dose-dependent increase in necrosis and enhanced proliferation as well as morphological damage. In addition, mucous cell area was found to decrease significantly after irradiation. The study shows the value of these primary cultures as in vitro models for studying radiation effects. They provide an effective alternative to whole-animal exposures for radiation risk assessment. (c) 2004 by Radiation Research Society

\section{INTRODUCTION}

Fish skin is continuously exposed to and in intimate contact with the aquatic environment. The epidermis, which is covered with a layer of mucus that forms an additional barrier to potentially harmful substances, protects the animal against external effects (1). Unlike the gill epithelium, the impact of environmental pollutants on this tissue has received little attention, although it is metabolically very active and responds rapidly to a wide variety of stressors (2-9). It is an important route of entry for waterborne radioisotopes in the environment and is likely to show effects of direct contact with contaminated water containing radio-

\footnotetext{
${ }^{1}$ Corresponding author: Radiation and Environmental Science Centre, Dublin Institute of Technology, Kevin St, Dublin 8, Ireland; e-mail: fiona.lyng@dit.ie.

${ }^{2}$ Present address: Medical Physics \& Applied Radiation Sciences, McMaster University, Hamilton, Ontario, Canada.
}

active substances due to releases from nuclear power stations.

There are few reports in the literature relating to the effects of low levels of ionizing radiation on fish. Much of the work details the effects of very high doses of radiation, which are not relevant for environmental protection applications.

While there is some literature on fish radiobiology, much of the data are for medaka, Oryzias latipes, which has been used as a model system for the study of germ cell mutagenesis after exposure to ionizing radiation (10). In addition to work done on medaka, Knowles (11) reported an immune response in rainbow trout exposed to chronic $\gamma$ radiation for 246 days after fertilization. The total accumulated dose over the whole period was 5-25 Gy. Goncharova et al. (12) described genetic effects of low-dose chronic irradiation (0.4-5.5 $\mu$ Gy per day) in carp from ponds radiocontaminated by the Chernobyl accident. There are some studies on the effects of UV radiation on fish. Effects of UV radiation on the eye lens of rainbow trout have been reported $(13,14)$. O'Reilly and Mothersill (15) documented that a fish cell line, EPC, was more sensitive to UVA and UVB radiation than were the human cell lines HPV-G and HaCaT. Cellular changes characteristic of sunburn damage have been reported in sole, Solea solea, exposed to UVB radiation, whereas turbot, Scophthalmus maximus, with its heavily pigmented skin, was found to be unaffected by similar doses (16). UVB-radiation-mediated increases in oxidative stress in muscle and skin of zebrafish, Brachydero rerio, have also been documented (17).

Tissue and cell culture systems are extremely useful for studying the behavior of cells independent of systemic control (18), and fish cells have been used in vitro for the assessment of the toxicity of environmental pollutants to aquatic biota (19). This laboratory developed a primary culture model system of rainbow trout skin (20) and has studied the effects of various environmental agents on this in vitro model. Lyons-Alcantara et al. $(3,4)$ investigated the effects of sublethal doses of cadmium and reported growth reduction, increased apoptosis, increased glycogen deposits and melanization, and increased heat-shock protein expres- 
STRESS RESPONSE IN IRRADIATED FISH SKIN PRIMARY CULTURES

sion. Reduction in growth, decreases in mucous cell number, and necrosis were reported after exposure to nonoxynol, copper and prochloraz $(6,7)$. Kilemade and Mothersill $(8,9)$ reported inhibited epidermal cell proliferation, necrotic epidermal cell death, and increased heat-shock protein expression after exposure to 2,4-dichloroaniline.

Apart from their critical importance in aquatic food webs, fish, as lower vertebrates, are an important species for mechanistic studies of radiation biology, because an understanding of the evolution of protective mechanisms may be gained. The aim of the present study is to investigate the effect of $\gamma$ radiation on primary cultures of rainbow trout skin. In an effort to understand mechanisms of damage response in fish, end points relating to apoptosis, necrosis and proliferation were examined in relation to dose. Morphological and functional changes were also studied.

\section{MATERIALS AND METHODS}

\section{Primary Culture of Rainbow Trout Skin}

Healthy rainbow trout (Oncorhynchus mykiss), 35-50 g, were obtained from a commercial fish farm in Co. Tipperary, Ireland. Rainbow trout parr were used in these experiments. The animals were killed humanely by a qualified veterinary practitioner (ML), and the procedure was approved by the Dublin Institute of Technology ethics committee. Epithelial cell growths were initiated from the skin explants using a technique described elsewhere $(3,20)$. Briefly, fish were aseptically dissected immediately after death. Care was taken to avoid contamination or damage to the outermost epidermal cells. Skin tissue was cleaned of muscle and fibrous tissue to avoid fibroblastic growth and cut into 2- $\mathrm{mm}^{2}$ pieces while immersed in sterile PBS or growth medium. It was not necessary to digest the tissue with enzymes. Single pieces of tissue were plated in the center of $25-\mathrm{cm}^{2}$ Falcon flasks containing $2 \mathrm{ml}$ RPMI 1640 growth medium containing 13\% fetal calf serum (Gibco Biocult, Scotland), 7\% horse serum (Gibco Biocult), $100 \mathrm{mIU}$ insulin (Novo Nordisk, Copenhagen), $1 \mu \mathrm{g} / \mathrm{ml}$ hydrocortisone (Glaxo), $50 \mathrm{IU} / \mathrm{ml}$ penicillin, $50 \mu \mathrm{g} / \mathrm{ml}$ streptomycin solution (Gibco Biocult) and $1 \mu \mathrm{g} / \mathrm{ml}$ fungizone/amphotericine B (Gibco). Cultures were incubated in a refrigerated incubator (Leec, Nottingham, UK) at $19^{\circ} \mathrm{C}$ in an atmosphere containing 95\% air/ $5 \% \mathrm{CO}_{2}$.

\section{Irradiation}

Explant cultures were irradiated in situ on the culture flasks 5 days after explantation. The dose was delivered at room temperature using a ${ }^{60} \mathrm{Co}$ teletherapy unit at a flask-to-source distance of $80 \mathrm{~cm}$. Under these conditions, the dose rate was approximately $1.9 \mathrm{~Gy} / \mathrm{min}$ during the experiments. The control cultures were removed from the incubator and brought to the ${ }^{60} \mathrm{Co}$ teletherapy unit with the irradiated cultures but were not irradiated. After irradiation, the cultures were replaced in the refrigerated incubator and maintained there until they were processed $48 \mathrm{~h}$ later. The doses used for these experiments were 0.5, 5, 10 and $15 \mathrm{~Gy}$.

\section{Growth Measurement}

Cultures derived from the explants were fixed in 10\% formalin 2 days after irradiation and were stained with Harris hematoxylin. Epithelial cell outgrowths were recorded using a transparent sheet of $1-\mathrm{mm}^{2}$ grid paper. The number of $1-\mathrm{mm}^{2}$ grids covered by the stained explant was counted.

\section{Immunocytochemistry}

An avidin-biotin immunoperoxidase method was used to visualize BCL2, c-myc and PCNA antibodies. Fish skin primary cultures, fixed 2 days after irradiation in $10 \%$ formalin for $5 \mathrm{~min}$, were transferred to PBS and assayed immediately. The explant outgrowth was processed in situ on the flask bottom to enable spatial distribution to be related to the type of cell and degree of differentiation. The expression system used was a Vectastain ABC kit (Vectastain Corporation Burlingame, CA), which follows an indirect immunoperoxidase technique. Endogenous peroxidase enzyme activity was quenched using $3 \%$ hydrogen peroxide. Cultures were then incubated with normal blocking serum. The outgrowths were exposed to monoclonal anti-mouse PCNA (clone PC-10), BCL2 (Dako Ltd, Uden, The Netherlands), and c-myc (clone 9E10, a gift from G. Evan, then at ICRF, London) antibodies. Cultures were incubated with the Vectastain ABC reagent (avidin-biotin peroxidase solution). Diaminobenzine tetrachloride (DAB) was used to visualize the reaction, and cultures were lightly counterstained with Harris hematoxylin. A positive reaction gives a brown product. Positive controls were from a positive human tissue block, obtained from the Cell Pathology Laboratory, Dublin Institute of Technology. Negative controls were cultures to which all reagents apart from the primary antibody were added. Positive and negative controls were run with every immunocytochemistry run-to-run to correct for run variability. Due to the small amounts of material (approximately $0.4 \mathrm{mg}$ total cells) and the desirability of using in situ approaches, it was not possible to check expression levels using Western blot analysis.

Quantification of Protein Expression, Apoptosis, Necrosis, Mucous Cell Number and Mucous Cell Area

Numbers of cells positive for PCNA, BCL2 and c-myc and numbers of apoptotic and necrotic cells and mucous cells were scored along transects drawn at right angles to each other through the middle of the outgrowth so that both the edge and the middle areas of the outgrowth were included in the count. Over 1000 cells were scored in each culture. Cells were scored as necrotic if they displayed swelling of the cytoplasm, organelle dissolution, plasma membrane rupture, or vacuolization. Cells were defined as apoptotic if they displayed evidence of two or more of the following: cell volume shrinkage and pyknotic nucleus (chromatin condensation), blebbing of the cytoplasm, nuclear fragmentation and formation of apoptotic bodies (21). TEM was used to confirm the presence of apoptotic cells. Mucous cells were recognized by their basophilic cytoplasm, basally located nuclei, and the accumulation of mucus secretory granules that filled and distended their apex to give the characteristic goblet shape (22). Mucous cell areas were measured using a Leica Q500MC image analyzer (Leica Microsystems, Germany). At least 300 mucous cells measured along transects drawn at right angles to each other were scored per dose.

\section{Transmission Electron Microscopy}

After the cultures were washed in buffer, they were fixed in $2.5 \%$ (v/ v) glutaraldehyde in $0.1 \mathrm{M}$ phosphate buffer for $1 \mathrm{~h}$, post-fixed in $1 \%$ $\mathrm{OsO}_{4}$ in $0.1 \mathrm{M}$ phosphate buffer for a further hour, dehydrated in ascending grades of ethanol, and subsequently embedded in epoxy resin. Thick sections $(2 \mu \mathrm{m})$ were cut en face with a glass knife, stained with $0.1 \%$ toluidine blue, and examined under the light microscope. Thin sections $(80 \mathrm{~nm})$ were then cut from the same block face with a diamond knife, mounted on 100 mesh unsupported copper grids, stained with uranyl acetate and lead citrate, and examined using a JEOL 2000 transmission electron microscope. Three areas of the cell outgrowth from three replicate cultures were examined at the ultrastructural level.

\section{Statistical Analysis}

All experiments were repeated three times, and within each experiment cultures were set up in triplicate. Results are expressed as the means \pm standard errors. Significance was determined using the $t$ test. 


\section{LYNG ET AL.}

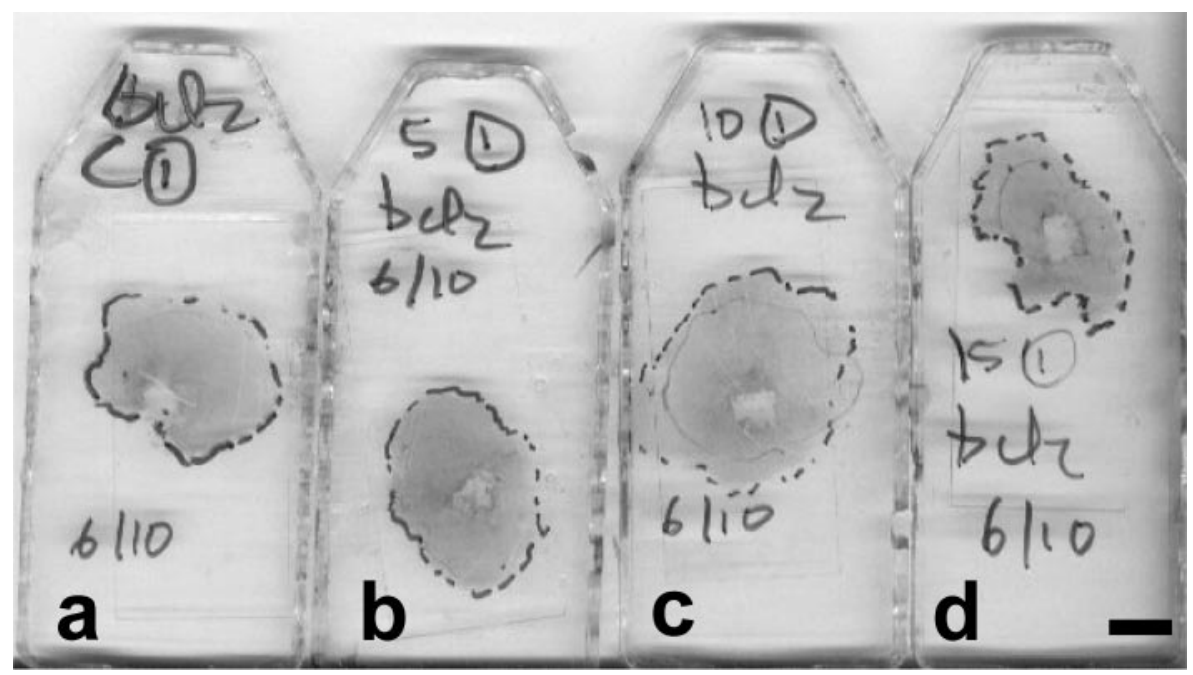

FIG. 1. Outgrowth areas from primary cultures of rainbow trout skin exposed to (a) 0 Gy (b) 5 Gy, (c) 10 Gy and (d) 15 Gy $\gamma$ radiation. Bar $=1 \mathrm{~cm}$.

\section{RESULTS}

\section{Effect of Radiation on Growth}

Figure 1 and Table 1 show the outgrowth area of control and irradiated rainbow trout skin primary cultures. No significant difference was observed between control cultures and those exposed to radiation.

\section{Ultrastructural Morphology}

The epidermis of fish skin is a stratified squamous epithelium. Mucus-secreting cells usually originate in the middle layers of the epidermis and increase in size as they approach the surface. Skin from rainbow trout showed polygonal epithelial cells with closely opposed plasma membranes and centrally placed nuclei and occasional ovalshaped mucous cells with basally located nuclei (Fig. 2a). Numerous desmosome junctions and intermediate filaments were present, and free ribosomes were abundant in the cytosol (Fig. 2b).

Primary cultures of rainbow trout skin showed polygonal epithelial cells with centrally placed nuclei. Oval-shaped

TABLE 1

Effect of Ionizing Radiation on Growth, Number of Mucous Cells, and Expression of PCNA in Primary Cultures of Rainbow Trout Skin

\begin{tabular}{|c|c|c|c|c|}
\hline \multirow[b]{2}{*}{ Dose } & \multirow[b]{2}{*}{$\begin{array}{l}\text { Outgrowth } \\
\text { area }\left(\mathrm{mm}^{2}\right)\end{array}$} & \multirow[b]{2}{*}{$\begin{array}{l}\text { Percentage } \\
\text { mucous cells }\end{array}$} & \multicolumn{2}{|c|}{$\begin{array}{c}\text { Percentage } \\
\text { PCNA-positive cells }\end{array}$} \\
\hline & & & $\begin{array}{l}\text { Very dark } \\
\text { staining }\end{array}$ & $\begin{array}{c}\text { Weak } \\
\text { staining }\end{array}$ \\
\hline 0 Gy & $210 \pm 55$ & $2.4 \pm 0.5$ & $13.0 \pm 1.0$ & $13.0 \pm 3.1$ \\
\hline $5 \mathrm{~Gy}$ & $193 \pm 75$ & $2.3 \pm 0.7$ & $11.5 \pm 0.5$ & $14.0 \pm 6.0$ \\
\hline $10 \mathrm{~Gy}$ & $235 \pm 65$ & $2.2 \pm 0.8$ & $17.3 \pm 5.2$ & $11.7 \pm 1.8$ \\
\hline 15 Gy & $213 \pm 35$ & $1.9 \pm 0.4$ & $22.0 \pm 7.0^{a}$ & $15.0 \pm 1.0$ \\
\hline
\end{tabular}

${ }^{a} P<0.05$. mucous cells were also observed (Fig. 2c). Desmosome junctions and intermediate filaments were present, confirming the epithelial nature of the cells (Fig. 2d, e).

Primary cultures of rainbow trout skin exposed to 0.5 and 5 Gy $\gamma$ radiation showed normal polygonal epithelial cells with occasional mucous cells. No changes in morphology were seen at these doses.

After the higher doses of 10 and 15 Gy, cells with irregular elongated nuclei and increased vacuolization were observed. Desmosome junctions were intact and intermediate filaments were present. Apoptotic cells showing condensed chromatin and a shrunken morphology were also seen (Fig. 2f). These were quantified using light microscopy (Table $1)$.

\section{Apoptosis}

Figure $3 \mathrm{a}$ shows the percentage of cells with morphological changes indicative of apoptosis in control and irradiated primary skin cultures. The results show that apoptosis is not an important response mechanism in this system.

\section{Necrosis}

Figure $3 \mathrm{a}$ shows the percentage of cells with morphological evidence of necrosis in control and irradiated primary skin cultures. There was a significant increase in the numbers of necrotic cells after irradiation.

\section{Mucous Cells}

Mucous cells were present in the controls and were distributed all over the outgrowths (Fig. 2c). Table 1 shows the effect of radiation on mucous cell numbers in outgrowths exposed to radiation. Radiation exposure did not significantly affect the percentage of mucous cells. Figure $3 b$ shows the effect of radiation on mucous cell area. A 

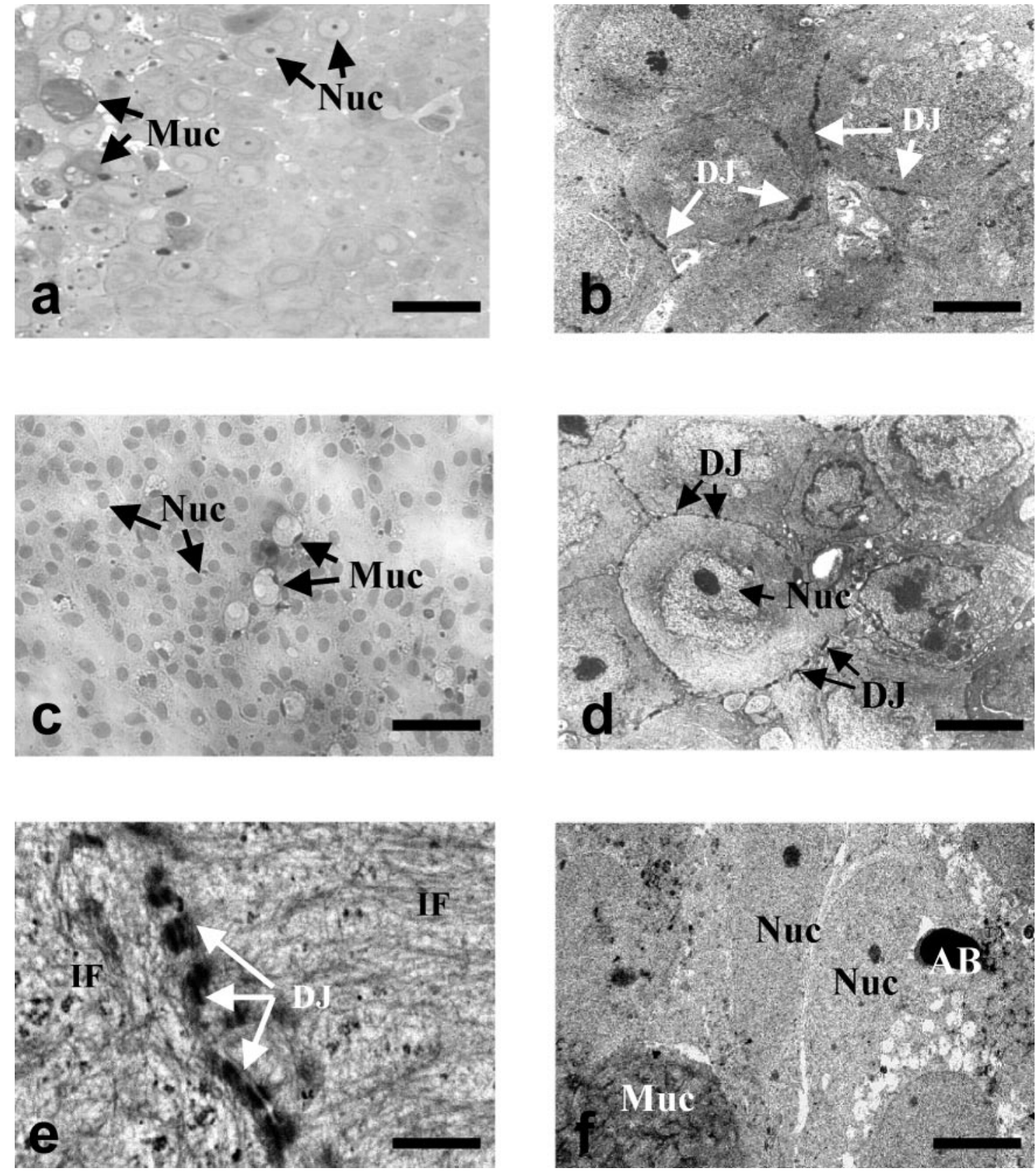

FIG. 2. Panel a: Skin from control rainbow trout showing polygonal epithelial cells with closely opposed plasma membranes and centrally placed nuclei (Nuc). Oval-shaped mucous cells (Muc) were observed occasionally. Bar $=20 \mu \mathrm{m}$. Panel b: Skin from control rainbow trout showing desmosome junctions (DJ). Free ribosomes are abundant in the cytosol. Bar $=5 \mu \mathrm{m}$. Panel c: Primary culture from rainbow trout skin showing polygonal epithelial cells with centrally placed nuclei (Nuc). Oval-shaped mucous cells (Muc) were also observed. Bar $=20 \mu \mathrm{m}$. Panel d: Primary culture from rainbow trout skin showing a regular nucleus (Nuc) and desmosome junctions (DJ). Bar $=5 \mu \mathrm{m}$. Panel e: Primary culture from rainbow trout skin showing intermediate filaments (IF) and desmosome junctions (DJ). Bar $=1 \mu \mathrm{m}$. Panel f: Primary culture from rainbow trout skin exposed to 10 Gy $\gamma$ radiation showing elongated nuclei (Nuc), an apoptotic body ( $\mathrm{AB}$ ), and a mucous cell (Muc). Bar $=5 \mu \mathrm{m}$.

significant dose-dependent reduction in mucous cell area was observed after irradiation.

\section{Expression of PCNA, c-myc and BCL2}

Table 1 shows the percentage of PCNA-positive cells in control and irradiated skin primary cultures. Both very darkly stained (equal to or more intense than the positive control) and weakly stained (less intense than the positive control) PCNA-positive cells were scored. The percentage of weakly stained cells did not change significantly with increasing radiation dose, but the percentage of darkly stained cells increased significantly at 10 and $15 \mathrm{~Gy}$.

Figure $3 \mathrm{c}$ shows the percentage of c-myc-positive cells in control and irradiated cultures. The percentage of c-myc- 

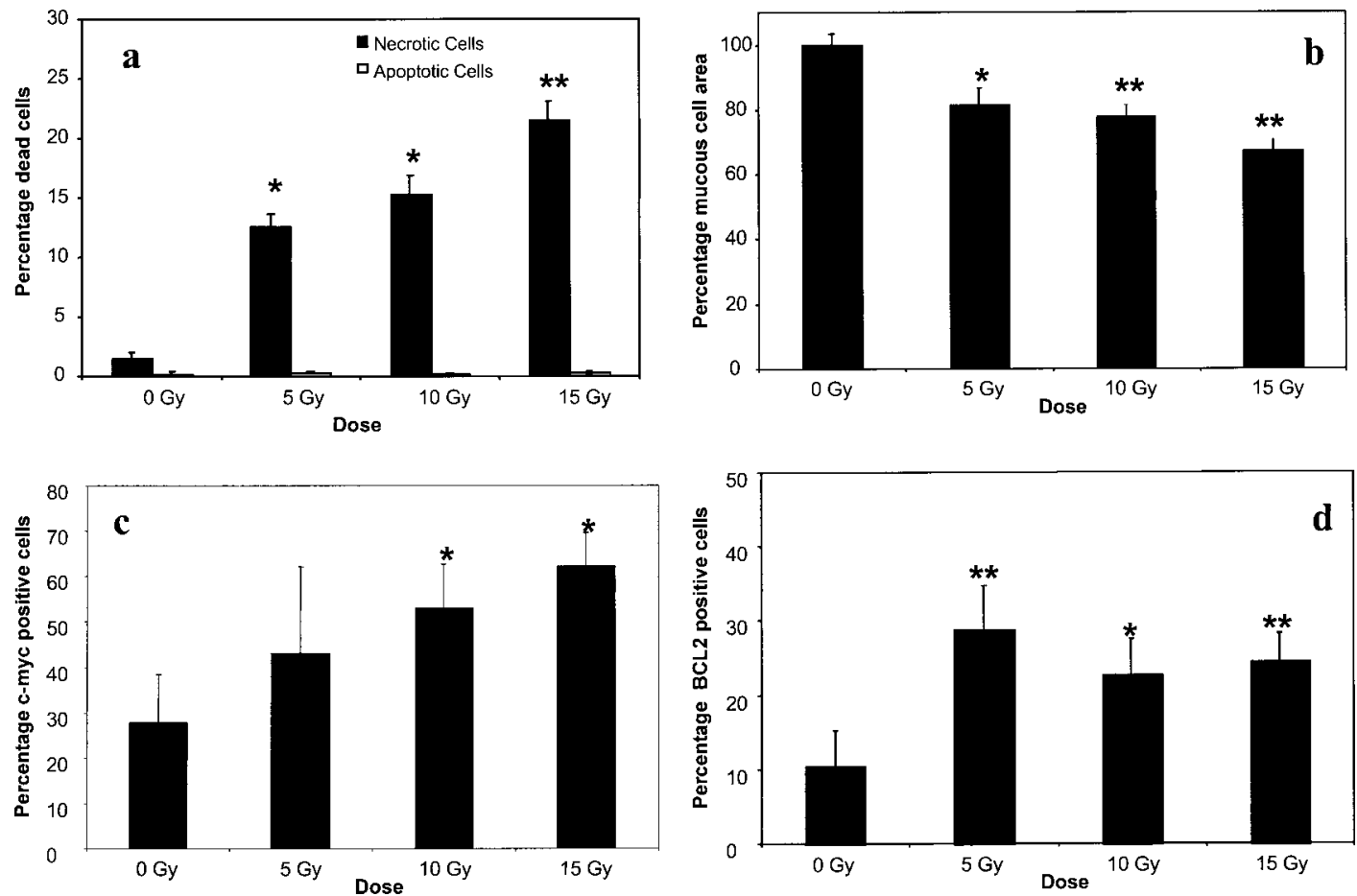

FIG. 3. Panel a: Percentages of necrotic and apoptotic cells in rainbow trout skin primary cultures exposed to radiation. Data are presented as means \pm standard deviations. $* P<0.01$, $* * P<0.001$. Panel b: Percentage reduction in mucous cell areas compared to controls in rainbow trout skin primary cultures exposed to radiation. Data are presented as means \pm standard deviations. $* P<0.05, * * P<0.005$. Panel c: Percentage c-myc-positive cells in rainbow trout skin primary cultures exposed to radiation. Data are presented as means \pm standard deviations. $* P<$ 0.01. Panel d: Percentage BCL2-positive cells in rainbow trout skin primary cultures exposed to radiation. Data are presented as the means \pm standard deviations. $* P<0.05, * * P<0.01$.

positive cells was found to increase with increasing radiation dose.

Figure 3d shows the percentage of BCL2-positive cells in control and irradiated cultures. An increase in the percentage of BCL2-positive cells was observed after radiation exposure.

\section{DISCUSSION}

This study showed increased necrosis and enhanced expression of PCNA, c-myc and BCL2 in primary cultures of rainbow trout skin exposed to $\gamma$ radiation. Morphological changes and functional changes involving mucous cells were also observed. No change in outgrowth area or in the number of apoptotic cells was found after irradiation.

Cell proliferation was assessed using immunocytochemical staining of PCNA. Ortega et al. (23) found that PC10 , the clone used in the present study, gave the best results out of three PCNA antibodies in three fish species. In the present study, cells showed both weak and intense nuclear staining of PCNA. The intense staining observed was indicative of cells in the $\mathrm{S}$ phase of the cell cycle, whereas the weakly stained fraction was indicative of noncycling cells $(24,25)$. Only cells with intensely positive nuclei, reflecting newly synthesized PCNA from actively cycling cells, showed a dose-dependent response to radiation. The increased expression of PCNA with increasing dose indicates enhanced proliferation after irradiation. The concomitant increase in the number of necrotic cells could explain the similar outgrowth areas observed in the control and irradiated cultures.

An increase in the expression of both c-myc and BCL2 was observed, with no change in the number of apoptotic cells. Aberrant expression of c-myc is known to cause apoptosis, but c-myc is also essential for cell proliferation $(26$, $27)$. It is thought that every cell that enters the cell cycle invokes a suicide pathway that must be continuously suppressed by signals from the immediate cellular environment for the proliferating cell to survive (27). In this case, it appears that increased expression of BCL2 inhibits the removal of damaged cells by apoptosis. C-myc and BCL2 family proteins have been identified previously in rainbow trout and other fish (28-31).

The pattern of expression of apoptosis and necrosis found in this study is similar to that seen by our group for both human uroepithelium and prawn hematopoietic tissue after exposure to ionizing radiation $(32,33)$. BCL2 and cmyc are both expressed, and necrosis appears to be the predominant mechanism of cell death. Primary cultures from fish skin and human uroepithelium appear to have similar sensitivities to radiation, whereas cultures from the prawn hematopoietic tissue appear to be considerably more 
STRESS RESPONSE IN IRRADIATED FISH SKIN PRIMARY CULTURES

sensitive. Current investigations involving primary cultures of rainbow trout pronephros (the main hematopoietic tissue) suggest that when like tissues are compared, the trout is more radioresistant than the prawn (34).

Morphological changes were also observed after irradiation. Changes in nuclear shape were observed as well as increased vacuolization. Nuclear irregularities may be a consequence of an increase in metabolic activity or a disturbance of mitosis. Rupture of cellular organelles leading to vacuolization may be due to increased water inflow caused by a disturbance of ionic concentration (35).

A functional change involving the mucous cells was also observed. Although no change in the numbers of mucous cells was seen, the mucous cell area was found to decrease significantly after irradiation. This may have been due to the mucous cells releasing their contents onto the cell culture surface in response to the radiation-induced stress. An increase in mucus production is a well known response to stress. Dowling and Mothersill (7) reported a decrease in the number of mucous cells in primary rainbow trout cultures after exposure to copper and prochloraz and also showed increased PAS staining for mucus in the exposed cultures. This stimulation of mucous secretion in rainbow trout skin was similar to that reported previously for fish exposed to ecological stressors (36).

This study has shown effects of $\gamma$ radiation on primary cultures of rainbow trout skin and shows the value of primary cultures as an in vitro model for radiation biology studies of complex organisms in their natural environment. In vitro studies can be used as a very effective alternative to whole animal exposures. Kilemade and Mothersill (37) reported good correspondence between in vivo and in vitro results for identifying toxic effects in fish skin. In vitro studies enable the response to a single agent to be examined in a single tissue, allowing mechanistic studies and doseresponse studies to be performed in a controlled way. A key point is to determine whether function of the tissue in the fish is impaired by radiation exposure. While death of the cells is a key determinant of dose effect in human radiobiology, fish or other species could die as a result of impaired function of defense systems, and that "indirect" effect could have consequences that are not readily detected using conventional assays for radiation damage.

\section{ACKNOWLEDGMENTS}

We are grateful to St. Luke's Hospital, Dublin for continued access to the cobalt-60 source. This work has been carried out (in part) within the Dublin Institute of Technology's Facility for Optical Characterisation and Spectroscopy (FOCAS), funded by the Irish Government Programme for Research in Third Level Institutions.

Received: January 3, 2004; accepted: April 1, 2004

\section{REFERENCES}

1. M. Whitear, The skin of fishes including cyclostomes-Epidermis. In Biology of the Integument, Vol. 2, Vertebrates (J. Bereiter Hahn,
A. G. Matoltsy and K. S. Richards, Eds.), pp. 8-38. Springer, Heidelberg, 1986.

2. Y. Iger, H. A. Jenner and S. E. Wendelaar Bonga, Cellular responses in the skin of rainbow trout exposed to Rhine water. J. Fish Biol. 45 1119-1132 (1994).

3. M. Lyons-Alcantara, J. V. Tarazona and C. Mothersill, The differential effects of cadmium exposure on the growth and survival of primary and established cells from fish and mammals. Cell Biol. Toxicol. 12, 29-38 (1996).

4. M. Lyons-Alcantara, R. Mooney, F. Lyng, D. Cottell and C. Mothersill, The effects of cadmium exposure on the cytology and function of primary cultures from rainbow trout. Cell Biochem. Funct. 16, 113 (1998).

5. P. Burkhardt-Holm, H. Schmidt and W. Meier, Heat shock protein in brown trout epidermis after sudden temperature rise. Comp. Biochem. Physiol. A 120, 35-41 (1998).

6. K. Dowling and C. Mothersill, Use of rainbow trout primary epidermal cell cultures as an alternative to immortalised cell lines in toxicity assessment: A study with Nonoxynol. Environ. Toxicol. Chem. 18, 2846-2850 (1999).

7. K. Dowling and C. Mothersill, The further development of rainbow trout primary epithelial cell cultures as a diagnostic tool in ecotoxicology risk assessment. Aquat. Toxicol. 53, 279-289 (2001).

8. M. Kilemade and C. Mothersill, In vitro assessment of the toxicity of 2,4-dichloroaniline using rainbow trout primary epidermal cultures. Environ. Toxicol. Chem. 19, 2093-2099 (2000).

9. M. Kilemade and C. Mothersill, Heat shock protein 70 levels in rainbow trout primary epidermal cultures in response to 2,4-dichloroaniline exposure: A novel in vitro aquatic toxicity marker. Environ. Toxicol. 16, 253-259 (2001).

10. A. Shima and A. Shimada, The Japanese medaka, Oryzias latipes, as a new model organism for studying environmental germ-cell mutagenesis. Environ. Health Perspect. 102, 33-35 (1994).

11. J. F. Knowles, The effect of chronic radiation on the humoral immune response of rainbow trout (Onchorhynchus mykiss Walbaum). Int. $J$. Radiat. Biol. 62, 239-248 (1992).

12. R. I. Goncharova, Remote consequences of the Chernobyl disaster: Assessment after 13 years. In Low Doses of Radiation: Are They Dangerous? (E. B. Burlakova, Ed.) pp. 289-314. Nova Science Publishers, New York, 2000.

13. A. P. Cullen, C. A. Monteith-McMaster and J. G. Sivak, Lenticular changes in rainbow trout following chronic exposure to UV radiation. Curr. Eye Res. 13, 731-737 (1994).

14. D. J. Coughlin and C. W. Hawryshyn, Ultraviolet sensitivity in the torus semicircularis of juvenile rainbow trout (Oncorhynchus mykiss). Vision Res. 34, 1407-1413 (1994).

15. J. P. O'Reilly and C. Mothersill, Comparative effects of UV A and UV B on clonogenic survival and delayed cell death in skin cell lines from humans and fish. Int. J. Radiat. Biol. 72, 111-119 (1997).

16. I. McFadzen, S. Baynes, J. Hallam, A. Beesley and D. Lowe, Histopathology of the skin of UV-B irradiated sole (Solea solea) and turbot (Scophthalmus maximus) larvae. Mar. Environ. Res. 50, 273 277 (2000).

17. R. A. Charron, J. C. Fenwick, D. R. Lean and T. W. Moon, Ultraviolet-B radiation effects on antioxidant status and survival in the zebrafish, Brachydanio rerio. Photochem. Photobiol. 72, 327-333 (2000).

18. J. R. Freshney, Culture of Animal Cells: A Manual of Basic Techniques. Wiley-Liss, New York, 1994

19. T. Zahn and T. Braunbeck, Isolated fish hepatocytes as a tool in aquatic toxicology: Sublethal effects of dinitro-o-cresol and 2,4-dichlorophenol. Sci. Total Environ. (Suppl.), 721-734 (1993).

20. C. Mothersill, F. M. Lyng, M. Lyons and D. C. Cottell, Growth and differentiation of epidermal cells from the rainbow trout established as explants and maintained in various media. J. Fish Biol. 46, 10111025 (1995).

21. J. F. R. Kerr and B. V. Harmon, Definition and incidence of apoptosis. An historical perspective. In Apoptosis. The Molecular Basis of Cell 
LYNG ET AL.

Death (L. D. Tomei and F. O. Cope, Eds.) pp. 5-9. Cold Spring Harbor Laboratory, Cold Spring Harbor, NY, 1991.

22. L. Weiss, Cell and Tissue Biology. Urban and Schwarzenberg, Munich, 1988

23. L. S. Ortega, W. E. Hawkins, W. W. Walker, R. M. Krol and W. H. Benson, Detection of proliferating cell nuclear antigen in tissues of three small fish species. Biotech. Histochem. 69, 317-323 (1994).

24. R. Bravo and M. MacDonald-Bravo, Existence of two populations of cyclin/proliferating cell nuclear antigen during the cell cycle. Association with DNA replication sites. J. Cell Biol. 105, 1549-1554 (1987).

25. R. J. Scott, P. A. Hall and J. S. Haldane, A comparison of immunohistochemical markers of cell proliferation with experimentally determined growth fraction. J. Pathol. 165, 173-178 (1991).

26. Y. Shi, J. M. Glynn, L. J. Guilbert, T. G. Cotter, R. P. Bissonnette and D. R. Green, Role for c-myc in activation-induced apoptotic cell death in T cell hybridomas. Science 257, 212-214 (1992).

27. G. Evan, E. Harrington, A. Fanidi, H. Land, B. Amati and M. Bennett, Integrated control of cell proliferation and cell death by c-myc oncogene. Phil. Trans. R Soc. Lond. B 345, 269-275 (1994).

28. J. P. Panno and B. A. McKeown, Expression and regulation of the myc proto-oncogene in the pituitary gland of rainbow trout. Mol. Cell Endocrinol. 134, 81-90 (1997).

29. C. A. Carter, W. W. Ellington and R. J. Van Beneden, Confocal laser scanning microscopy of oncogene localisation in rainbow trout cel lines derived from normal and tumour tissue. Toxicol. Pathol. 24, 339-345 (1996).

30. J. R. Hong, Y. L. Hsu and J. L. Wu, Infectious pancreatic necrosis virus induces apoptosis due to down regulation of survival factor MCL-1 protein expression in a fish cell line. Virus Res. 63, 75-83 (1996).

31. M. C. Chen, H. Y. Gong, C. Y. Cheng, J. P. Wang, J. R. Hong and J. L. Wu, Cloning and characterization of a novel nuclear Bcl-2 family protein, zfMcl-1a, in zebrafish embryo. Biochem. Biophys. Res. Commun. 279, 725-731 (2000).

32. C. Mothersill, K. O'Malley, J. Harney, F. Lyng, D. M. Murphy and C. B. Seymour, Further investigation of the response of human uroepithelium to low doses of cobalt-60 gamma radiation. Radiat. Res. 147, 156-165 (1997).

33. C. Mothersill, F. Lyng, A. Mulford, C. Seymour, D. Cottell, M. Lyons and B. Austin, Effect of low doses of ionising radiation on cells cultured from the haematopoietic tissue of the Dublin bay prawn, Nephrops norvegicus. Radiat. Res. 156, 241-250 (2001).

34. P. Olwell, D. C. Cottell, S. Ni Shuilleabhain, M. Lyons Alcantara, C. Seymour, C. Mothersill and F. M. Lyng, Ultrastructural effects of ionising radiation on primary cultures of rainbow trout skin, spleen and pronephros. Proc. R. Microsc. Soc. 37, 2002

35. A. Goldfeder, Radiosensitivity at the subcellular level. Laval. Med. 34, 12-43 (1963).

36. Y. Iger, V. Hilge, and M. Abraham, The ultrastructure of fish skin during stress in aquaculture. In Progress in Aquaculture Research (B. Moav, V. Hilge and H. Rosenthal, Eds.), pp. 205-214. EAS Special Pub. No 17, Oostende, 1992.

37. M. Kilemade, M. Lyons-Alcantara, T. Rose, R. Fitzgerald and C Mothersill, Rainbow trout primary epidermal cell proliferation as an indicator of aquatic toxicity: an in vitro/in vivo exposure comparison. Aquat. Toxicol. 60, 43-59 (2002). 